\title{
Analisis Perbaikan Stern Tube Poros Propeller Single Screw pada Kapal General Cargo 4192 GT
}

\author{
Sulaiman*, Sunarso Sugeng, Mohammad Ridwan \\ Departemen Teknologi Industri, Sekolah Vokasi Universitas Diponegoro, \\ Jl. Prof. Soedarto, SH, Kampus Undip Tembalang, Semarang, Indonesia 50275 \\ *E-mail: sulaiman@lecturer.undip.ac.id
}

Diterima: 22-07-2021; Direvisi: 18-11-2021; Dipublikasi: 30-12-2021

\begin{abstract}
Abstrak
Suatu latar belakang kondisi dalam proses perencanaan kapal, pada tahap pemasangan poros propulsi di kapal, tentu saja diperlukan penyelarasan yang benar. Kesalahan dapat menyebabkan distribusi beban yang tidak merata pada bantalan, akibatnya menyebabkan abrasi yang tidak normal, kondisi kelebihan beban, kelebihan beban dan kerusakan pada bagian bantalan tertentu, hal tersebut berlaku juga kepada struktur yang mendapat beban statis sebagai tumpuannya. perlunya uji numerik untuk proses analisa terjadinya beban berlebih dalam persiapan reparasi bantalan poros propeller sehingga menunjukan karakter hidrodinamik dan beban yang terjadi ketika bantalan dan poros propeller mulai kontak. Tujuan penelitian ini,menganalisis desain bantalan poros propeller untuk direparasi dan untuk mendapatkan performa terbaik dari sistem kontak antara bantalan dengan poros propeller sehingga merepresentasikan perbandingan kinerja dari propeller sebelum dan sesudah perbaikan. Metode perhitungan dengan metode finite elemen berbasis persamaan matematik merepresentasikan tegangan yang terjadi sesuai karakter material bronze ( $\mathrm{AlBr}$ dan $\mathrm{CuSn}$ ) yang diaplikasikan pada performa bantalan proros propeller kapal tipe general cargo seberat 4192 GT. Hasil analisa menunjukan pada beban rpm 525 maka shear stress untuk stern tube material AlBr bernilai $978 \mathrm{Mpa}$ dan pada material SnCu bernilai $948 \mathrm{Mpa}$. Nilai deflect atau cleareance pada setiap posisi setelah dilakukan perbaikan mengalami peningkatan rata-rata sebesar 24,4\% dari pengukuran awal sebelum dilakukan reparasi. Proses reparasi menunjukan performa yang cukup baik, rata-rata temperatur kerja yang dihasilkan ketika dilakukan pengujian sea trial menurun dari sebelumnya sebesar 7,5\%.
\end{abstract}

Kata kunci: General Cargo; Poros Propeller; Reparasi; Single Screw; Stern Tube

\begin{abstract}
In the ship planning process, at the stage of installing the propulsion shaft on the ship, of course, proper alignment is required. Errors can cause uneven load distribution on the bearing, resulting in abnormal abrasion, overload conditions, overload and damage to certain bearing parts, this also applies to structures that receive static loads as their supports. the need for numerical tests for the process of analyzing the occurrence of overload in preparation for repair of propeller shaft bearings so that it shows the hydrodynamic character and the load that occurs when the bearing and propeller shaft start to contact. The purpose of this research,analyze the design of the propeller shaft bearing for repair and to get the best performance from the contact system between the bearing and the propeller shaft so that it represents a comparison of the performance of the propeller before and after repair. The calculation method using the finite element method based on mathematical equations represents the stress that occurs according to the character of the bronze material $(\mathrm{AlBr}$ and $\mathrm{CuSn})$ which is applied to the performance of the propeller bearing of a 4192 GT general cargo ship. The results of the analysis show at $525 \mathrm{rpm}$, the shear stress for stern tube AlBr material is $978 \mathrm{Mpa}$ and for SnCu material is $948 \mathrm{Mpa}$. The value of deflection or clearance at each position after repair has increased by an average of $24.4 \%$ from the initial measurement before repair. The repair process showed a fairly good performance, the average working temperature produced when the sea trial was tested decreased from the previous $7.5 \%$.
\end{abstract}

Keywords: General Cargo; Propeller Shaft; Repair; Single Screw; Stern Tube

\section{Pendahuluan}

Dalam proses perencanaan kapal, pada tahap pemasangan poros propulsi di kapal, tentu saja diperlukan penyelarasan yang benar [1,2]. Hal itu sangat penting untuk memastikan adanya distribusi beban yang stabil dan tepat ke bantalan pendukung poros [3,4,5]. Sehingga kemungkinan terjadinga keuasan pada poros propeller juga cukup kurang resikonya [6,7]. Kesalahan dapat menyebabkan distribusi beban yang tidak merata pada bantalan, akibatnya 
menyebabkan abrasi yang tidak normal, kondisi kelebihan beban, kelebihan beban dan kerusakan pada bagian bantalan tertentu, hal tersebut berlaku juga kepada struktur yang mendapat beban statis sebagai tumpuannya [8]. Dalam praktik konvensionalnya, beban lokal yang berlebihan pada bantalan dapat mengakibatkan terjadinya gesekan yang cukup besar sehingga tegangan yang terjadi dapat melebihi batas kekuatan material dan mengakibatkan deformasi pada bagian tertentu [9,10,11]. Gambar 1 menunjukan terdapat kerusakan pada bantalan poros propeller, dimana terjadi kerusakan keausan dan bagian material yang terkikis karena adanya pengaruh beban dari putaran poros propeller.
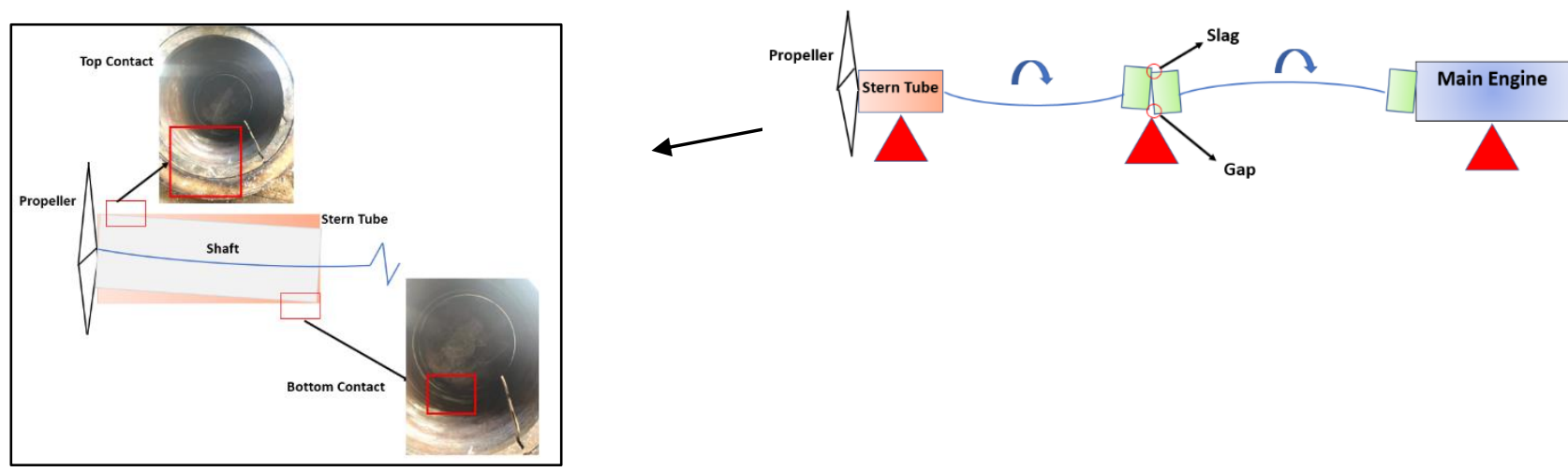

Gambar 1. Kondisi beban kerja Stren Tube Poros Propeller

Hasil penelitian sebelumnya mengungkapkan bahwa sudut kemiringan relatif antara poros penggerak dan bantalan poros propeller kapal telah menyebabkan terjadinya misalignment, yang mengakibatkan dampak buruk pada performa sistem poros propeller , dan akibatnya merusak bantalan $[10,11]$. Hasil analisis dari beberapa penelitian menyarankan bahwa derajat kemiringan diperhitungkan ketika memperkirakan titik tumpuan efektif bantalan terlebih ketika kapal beroperasi tentunya ada beban yang diterima bantalan selama proses tersebut [12,13]. Hipotesis sementara menunjukkan bahwa penetapan pedoman pemasangan poros propeller dengan mempertimbangkan efek kemiringan poros propeller dapat mempengaruhi pencegahan kerusakan pada bantalan poros propeller.Sementara itu penelitian lainnya, sebuah simulasi numerik yang difokuskan pada penyelidikan fenomena termal di bawah pengoperasian bantalan berpelumas air menunjukkan bahwa terdapat suatu aliran aksial terbatas yang mendorong aliran balik air dari zona sisi bantalan melalui alur yang telah terbantuk [14]. Sehingga dapat diketahui suhu aliran balik lebih tinggi dari suhu suplai awal pendingain oleh air karena dibawah kondisi aliran aksial yang terbatas, hal itu dipengaruhi terutama oleh suhu aliran air dari celah yang terdapat pada didalam bantalan poros propeller, yang lebih tinggi karena film pelumas [15]. Untuk itu perlunya dilakukan investigasi terkait proses reparasi yang mengambarkan efek yang terjadinya kenaikan suhu serta kemungkinan tegangan yang terjadi pada bantalan poros propeller. Pendekatan untuk perhitungan perubahan elevasi kemiringan bantalan dapat ditunjukan dengan persamaan gaya elastic [16] , dapat ditulis ulang sesuai dengan Pers. (1) :

$$
\Delta \boldsymbol{j}=\boldsymbol{\delta} \boldsymbol{j}-\boldsymbol{\gamma} \boldsymbol{j}
$$

Dimana nilai perbedaan defleksi dapat diketahui dari selisih antara yaitu defleksi antar bantalan (meter) dan dengan jarak antara bentalan dengan lambung kapal dalam meter. Kemudian jika di turunkan dalam persamaan gravitasi dan gerak transasional [7], maka dapat ditulis ulang sesuai dengan Pers. (2-5) :

$$
\begin{aligned}
& \gamma_{j}^{R}=\gamma_{j}^{L}=\gamma j \\
& \theta_{j}^{R}=\theta_{j}^{L}=\theta j \\
& M_{j}^{R}=M_{j}^{L}=\boldsymbol{M j}
\end{aligned}
$$




$$
Q_{j}^{R}+m_{j} \delta=Q_{j}^{L}+m_{j} \omega^{2} y_{j}+K_{s j} \Delta_{j}
$$

Dalam persamaan tersebut nilai adalah sudut yang terbantuk dari kemiringan shaft terhadap bantalan ditunjukan dalam bentuk radian. Sedangkan nilai M menunjukan momen dari beban poros yang terbentuk satuannya dalam N.m . Kemudian nilai $\mathrm{Q}$ adalah gaya shear yang direpresntasikan melalui tegangan yang terjadi dimana $\mathrm{m}$ adalah elemen dari masa, menunjukan radian kecepatan putaran shaft $(\mathrm{rpm})$, lalu g akselerasi gravitasi $\left(\mathrm{kg} / \mathrm{s}^{2}\right)$, Ks adalah bagian dari stifness $(\mathrm{N} / \mathrm{m})$, jarak perubahan antara bantalan dengan lambung (meter). Adapun gap dari penelitian sebelumnya perlunya uji numerik untuk proses analisa terjadinya beban berlebih dalam persiapan reparasi bantalan poros propeller sehingga menunjukan karakter hidrodinamik dan beban yang terjadi ketika bantalan dan poros propeller mulai kontak. Sedangkan pengaruh penggunaan tipe material berpengaruh terhadap hasil analisa tegangan pada bantalan poros propeller ketika beroperasi dan menghasilkan karakter tersendiri ditunjukan dari hasil analisa grafiknya. Sehingga dalam penelitian ini menghubungkan nilai numerik dengan karakter material bronze ( $\mathrm{AlBr}$ dan $\mathrm{CuSn}$ ) yang diaplikasikan pada performa bantalan proros propeller kapal tipe general cargo seberat 4192 GT . Korelasi dan hubungannya dengan penelitian terdahulu tersebut cukup terlihat dari penelitian ini adalah proses perbaikan bantalan poros propeller tipe single screw berserta kajian analisis beban pada desain bantalan setelah perbaikan. Pengaruh modifikasi juga ditinjau dari pengaruh kontak antara material bantalan poros propeller, pada sistem propulsi kapal yang berpengaruh terhadap performa propeller kapal serta hubunganya terhadap perbandingan performa. Hal ini merumuskan suatu hipotesis bahwa perencanaan desain stern tube poros propeller perlu diperhatikan guna mendapatkan peroforma terbaik dari bantalan dan poros propeller yang saling kontak. Demikian halnya dengan penelitian - penelitian yang dilakukan sebelumnya berkaitan dengan eksperimen simulasi modifikasi desain dan material bronze ( $\mathrm{AlBr}$ dan $\mathrm{CuSn}$ ) pada bantalan propeller kapal.

Secara garis besar batasan masalah dalam penelitian ini adalah bagian yang dilakukan perbaikan bantalan poros propeller pada sistem propulsi kapal general cargo 4192 GT , perhitungan simulasi desain bantalan propeller dengan Finite Element Method, kondisi gelombang sesuai dengan kondisi rata-rata perairan dalam di Indonesia, cuaca ketika pelaksaan sea trial cukup cerah. Sehingga berdasarkan pendahuluan dan beberapa kajian dari peneliti terdahulu maka tujuan dari penelitian ini adalah menganalisis desain bantalan poros propeller untuk direparasi dan untuk mendapatkan performa terbaik dari sistem kontak antara bantalan dengan poros propeller sehingga merepresentasikan perbandingan kinerja dari propeller sebelum dan sesudah perbaikan.

\section{Material dan metodologi}

Data kapal yang digunakan dalam penelitian ini, terdapat pada data Tabel 1. Data pengukuranporos propeller kapal besertaclereancedengan bantalannya terdapat pada Tabel 2. Alur metode yang digunakan adalah dengan menggambar ulang desain stren tube poros propeller model single screwuntuk kemudian dilakukan simulasi perhitungan dengan metode finite elemen. Kemudian dibandingkan dibuat model perbaikan berdasarkan desain yang telah di buat. Seperti terlihat pada Gambar 4, dapat terlihat alur penelitian dimana desain yang dibuat kemudian dibuat dan disimulasikan sebelum di produksi untuk dibuat. 
Sulaiman dkk /Jurnal Rekayasa Mesin p-ISSN: 1411-6863, e-ISSN: 2540-7678

Vol.16|No.3|369-378|Desember|2021

Tabel 1. Data Ukuran Utama Kapal

\begin{tabular}{cll}
\hline No. & \multicolumn{1}{c}{ Data Ukuran Utama Kapal } \\
\hline 1. & Nama Kapal & KM. LINTAS BRANTAS \\
2. & LOA & $111,90 \mathrm{~m}$ \\
3. & LBP & $105,27 \mathrm{~m}$ \\
4. & B & $16,00 \mathrm{~m}$ \\
5. & H & $7,60 \mathrm{~m}$ \\
6. & GT & 4192 Ton \\
\hline
\end{tabular}

Tabel2. Record of Propeller Shaft Clereance

\begin{tabular}{cccc}
\hline Location & Dia Bush ( mm) & Dia Shaft $(\mathbf{m m})$ & Clereance (mm) \\
\hline \multicolumn{3}{c}{ Before Repair } \\
TB & 429.89 & 351 & 78.89 \\
PSPB & 430.21 & 351 & 79.21 \\
AA & 429.96 & 351 & 78.96 \\
BB & 429.88 & 351 & 78.88 \\
& \multicolumn{2}{c}{ After Repair } \\
TB & 325.54 & 351 & 25.46 \\
PSPB & 325.59 & 351 & 25.41 \\
AA & 325.55 & 351 & 25.45 \\
BB & 325.56 & 351 & 25.44 \\
\hline
\end{tabular}

Agar memudahkan dalam membaca posisi dari pengukuran clereance maka dapat digambarkan seperti, lihat pada gambar 3 .

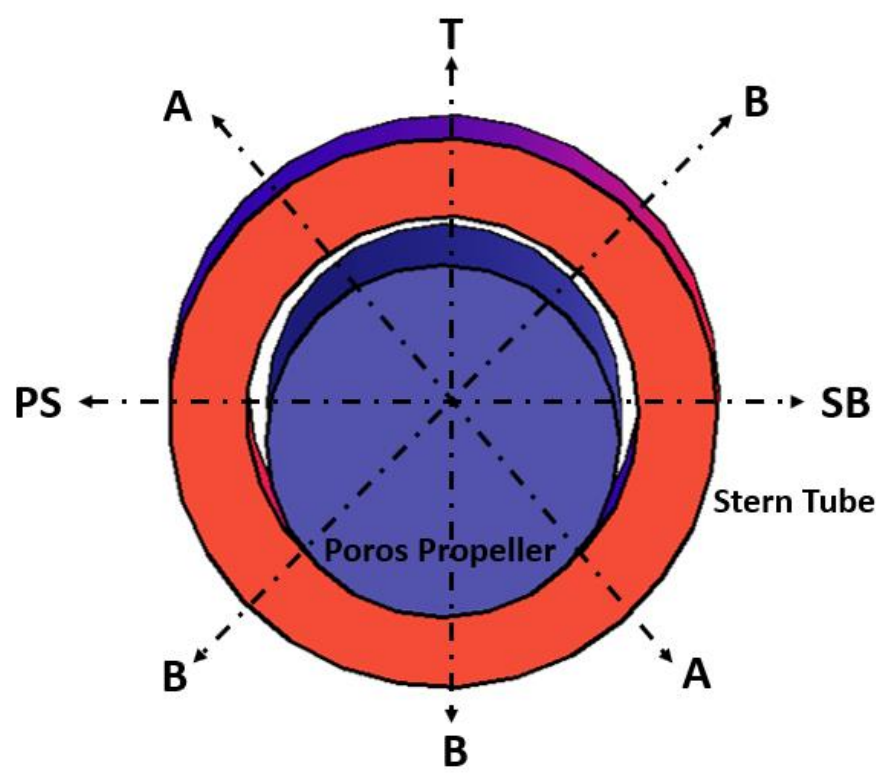

Gambar 3. Lokasi pengukuran clereance pada stern tube propeller shaft 
Sulaiman dkk /Jurnal Rekayasa Mesin

p-ISSN: 1411-6863, e-ISSN: 2540-7678

Vol.16|No.3|369-378|Desember|2021

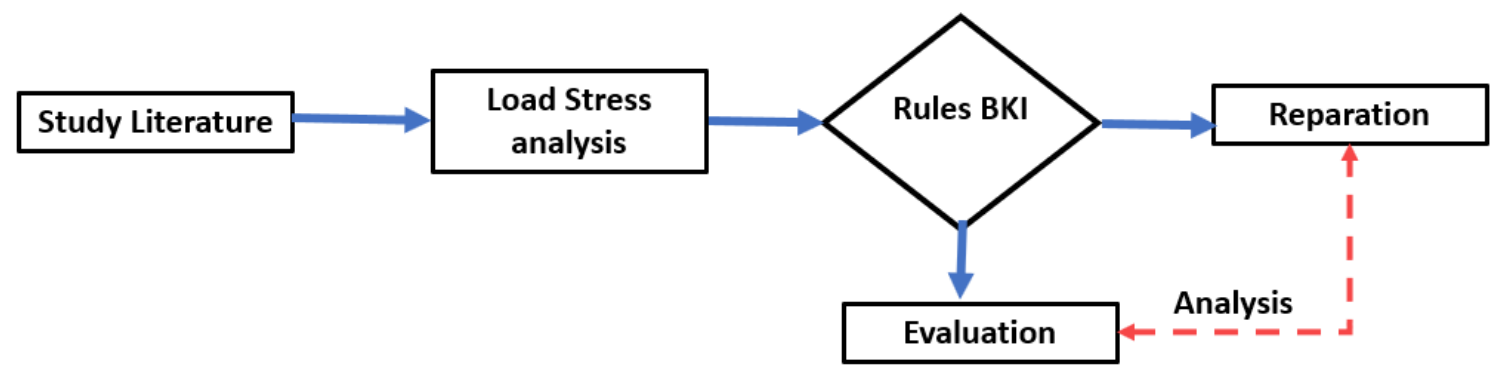

Gambar 4. Alur Penelitian

\section{Hasil dan pembahasan}

Hasil pemodelan kemudian dianalisa dan didapatkan nilai tegangan pada bagian beban kontak antara poros propeller dengan stern tube , pada material bronze (AlBr) memiliki nilai tegangan maksimum sebesar 878 Mpa sedangkan untuk material (CuSn) nilai tegangan maksimum sebesar 848 Mpa tentunya semua pada kondisi operasional yang menyesuaikan dengan keadaan maksimum rpm mesin. Dikarenakan data pada beban maksimum merupakan baban kinerja tertinggi pada poros propeller, dapat dilihat pada Gambar 5.

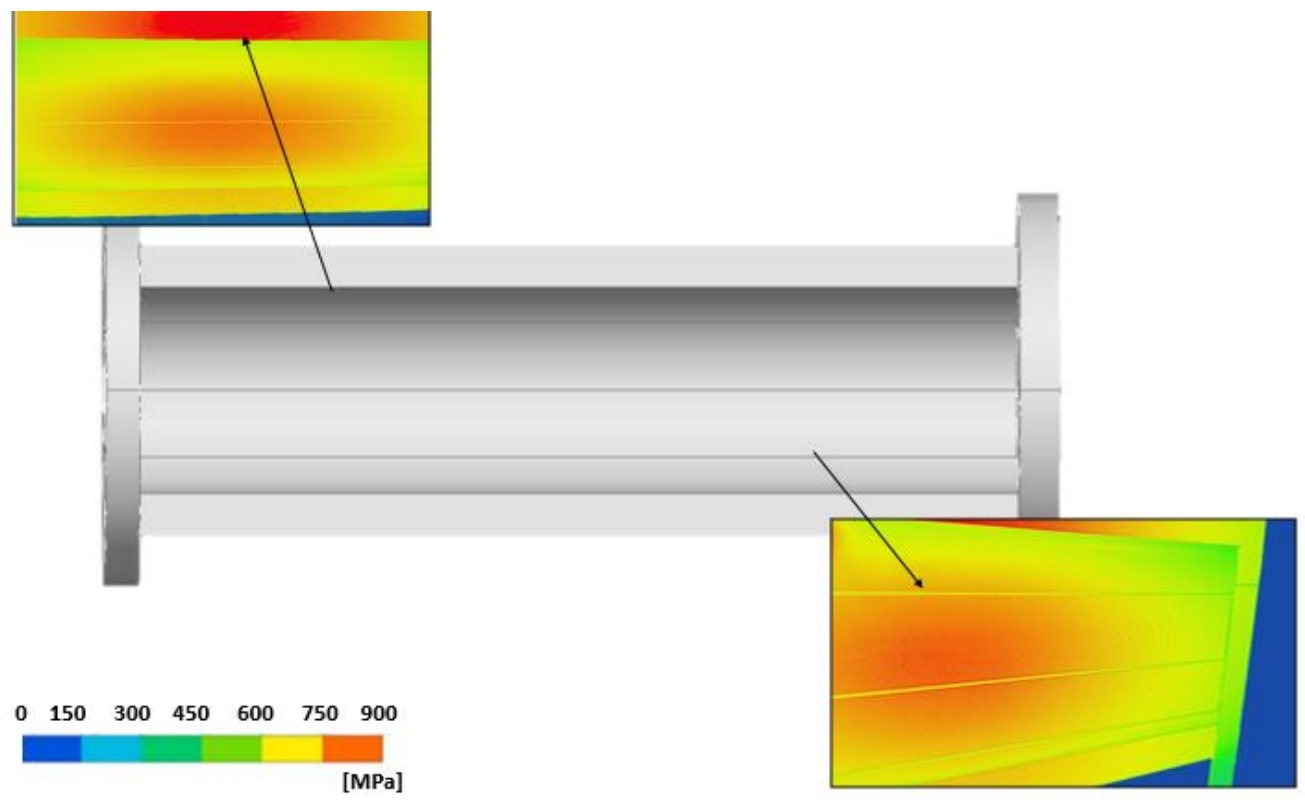

Gambar 5. Tegangan Maksimum pada stern tube

Dari Pers. (5) sesuai penjabarannya dari persamaan $(1,2,3,4)$ kemudian dilakukan perhitungan untuk menentukan dan menggambarkan kondisi performa stern tube propeller setelah dirancang. Setelah dilakukan data perbandingan maka diperoleh sesuai terlihat pada Gambar 6. Berdasakan Gambar 6 diketahui jika nilai teradapat pada kondisi maksimum load rpm yang berkerja pda poros propeller, sehingga kontak dengan stern tube memiliki nilai yang tinggi pula, dari grafik tersebut pada beban rpm 525 maka shear stress untuk stern tube material AlBr bernilai 978 Mpa dan pada material $\mathrm{SnCu}$ bernilai $948 \mathrm{Mpa}$. 
Sulaiman dkk /Jurnal Rekayasa Mesin

p-ISSN: 1411-6863, e-ISSN: 2540-7678

Vol.16|No.3|369-378|Desember|2021

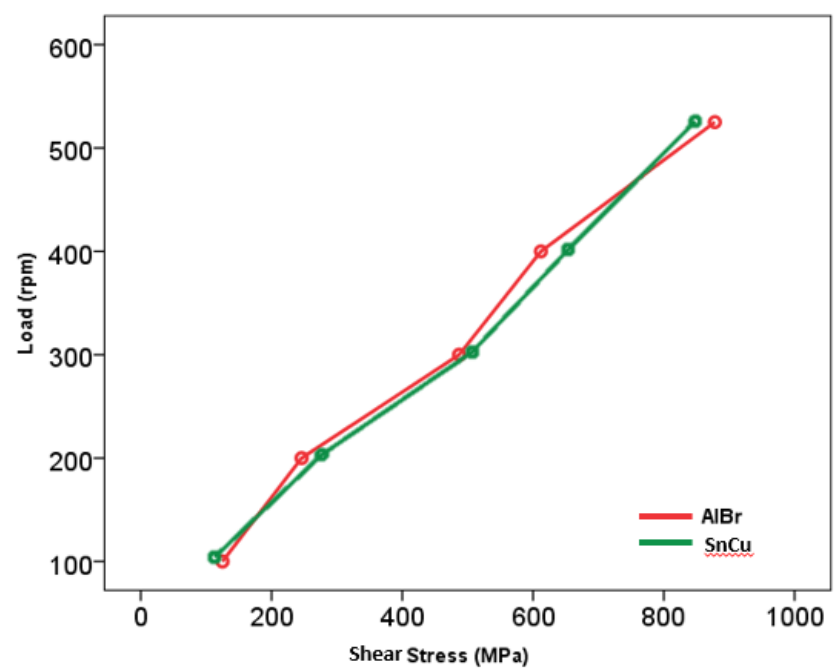

Gambar 6. Hasil Perhitugan Shear Stress berdasarkan beban stren tube

Terlihat pada Gambar 7, menunjukan pesoses perbaikan pada bagian bantalan poros propeller yang terdapat deformasi. Proses perbaikan ini menggunakan heat treatmen sehingga material dapat menjadi lunak dan mudah diatur. Kemudian setelah diluruskan maka dilakukan peroses pengelasan dan penggerindaan secara bertahap sehingga membentuk stren tube atau bantalan poros propeller yang diinginkan. Proses pengelasan dengan teknik pengelasan Oxyaceteline dimana elektroda atau material tambahan yang digunakan untuk bronze, lihat Gambar 8. Proses pengecekan setelah perbaikan dilakukan perbaikan dengan metode Non Destructive Test yaitu dengan menggunakan Dry Penetran Test, seperti terlihat pada Gambar 9.

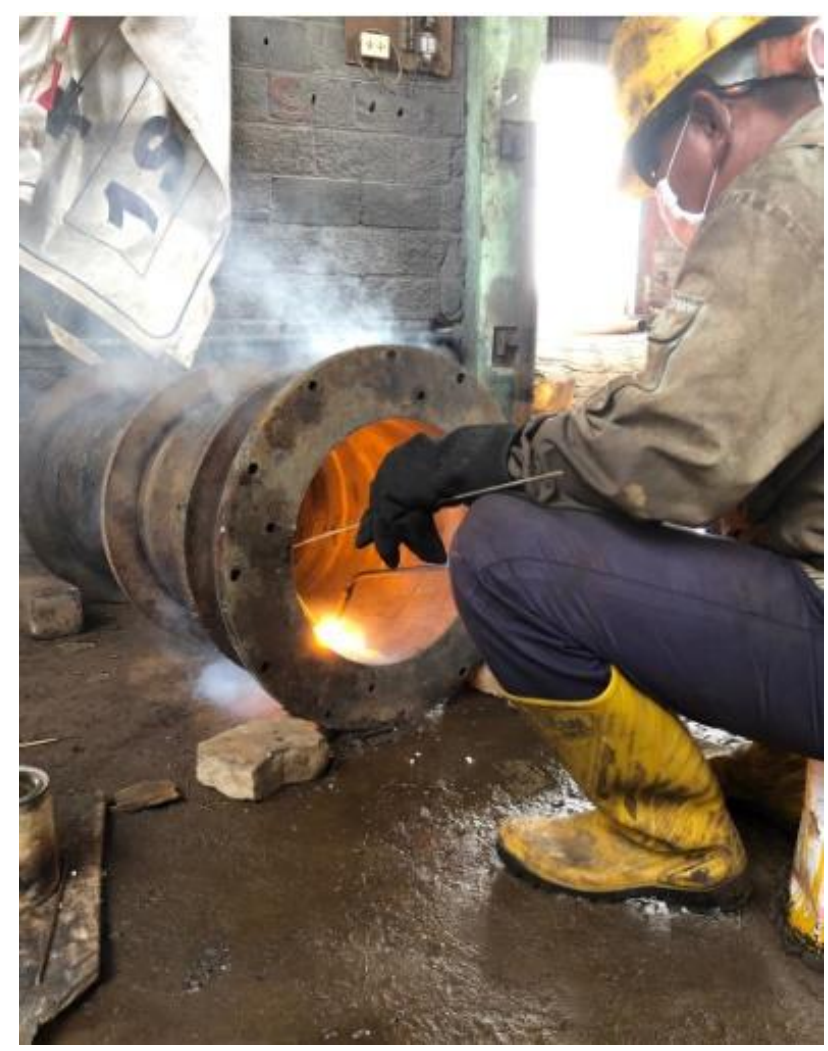

Gambar 8. Pengelasan Oxyaceteline untuk perbaikan stern tube 
Sulaiman dkk /Jurnal Rekayasa Mesin

p-ISSN: 1411-6863, e-ISSN: 2540-7678

Vol.16|No.3|369-378|Desember|2021

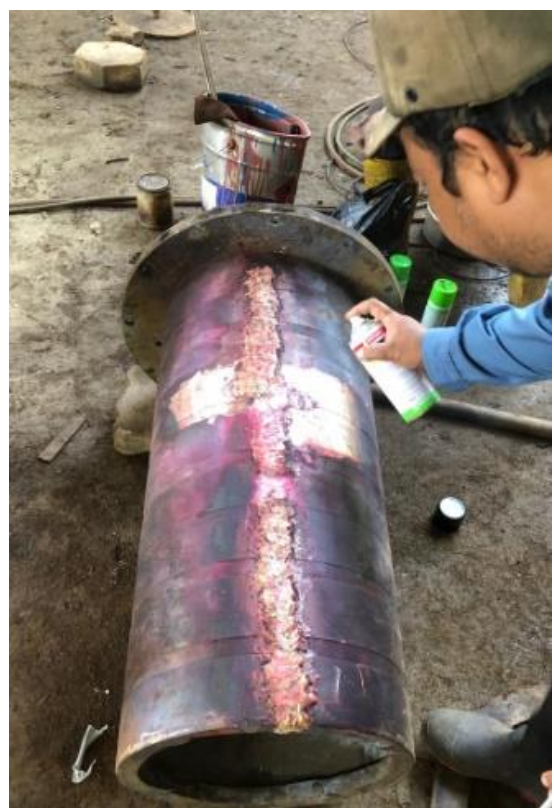

Gambar 9. Proses pengecekan hasil pengelasan stern tube

Hasil dari perbaikan disimpulkan untuk perbaikan stren tube poros propeller membutuhkan $12 \mathrm{~kg}$ bahan isian guna memperbiki bagian yang telah rusak atau deformasi tadi. Dari model pengelasan dan teknik perbaikannya tidak ditemukan cacat pengelasan sehingga hasil ini direkomendasikan oleh klasifikasi Indonesia (BKI). Hal tersebut senada dengan performa pengujian yang dilakukan, dari gambar 10 sesuai dengan persamaan (1), maka didapatkan nilai deflect atau cleareance pada setiap posisi setelah dilakukan perbaikan mengalami peningkatan rata-rata sebesar 24,4\% dari pengukuran awal sebelum dilakukan reparasi. Kondisi kritis yang paling menunjukan adanya perubahan yang sangat signifikan terdapat pada posisi TB sebesar 0,011 mm dan pada posisi PS - SB sebesar 0,032 mm. Hal tersbut menujukan putaran poros propeller dengan beban horizontal dan vertical sangat memengaruhi terjadinya keausan, deformasi tertentu pada permukaan dua buah kontak antara benda tersebut. Sedangkan pada bagian diagolan yaitu A-A dan B-B tidak begitu menunjukan adanya pengurangan yang cukup besar.

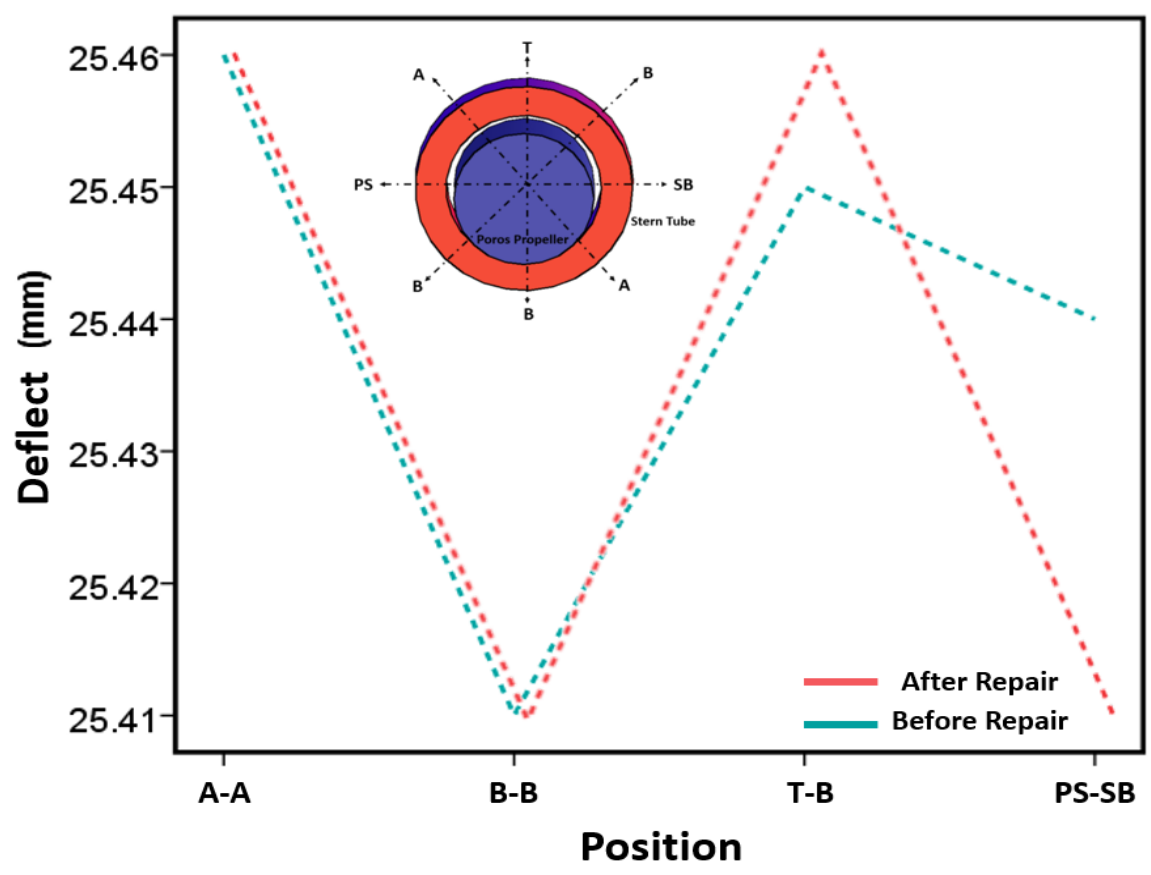

Gambar 10. Grafik Deflect pada tiap posisi 
Sulaiman dkk /Jurnal Rekayasa Mesin

p-ISSN: 1411-6863, e-ISSN: 2540-7678

Vol.16|No.3|369-378|Desember|2021

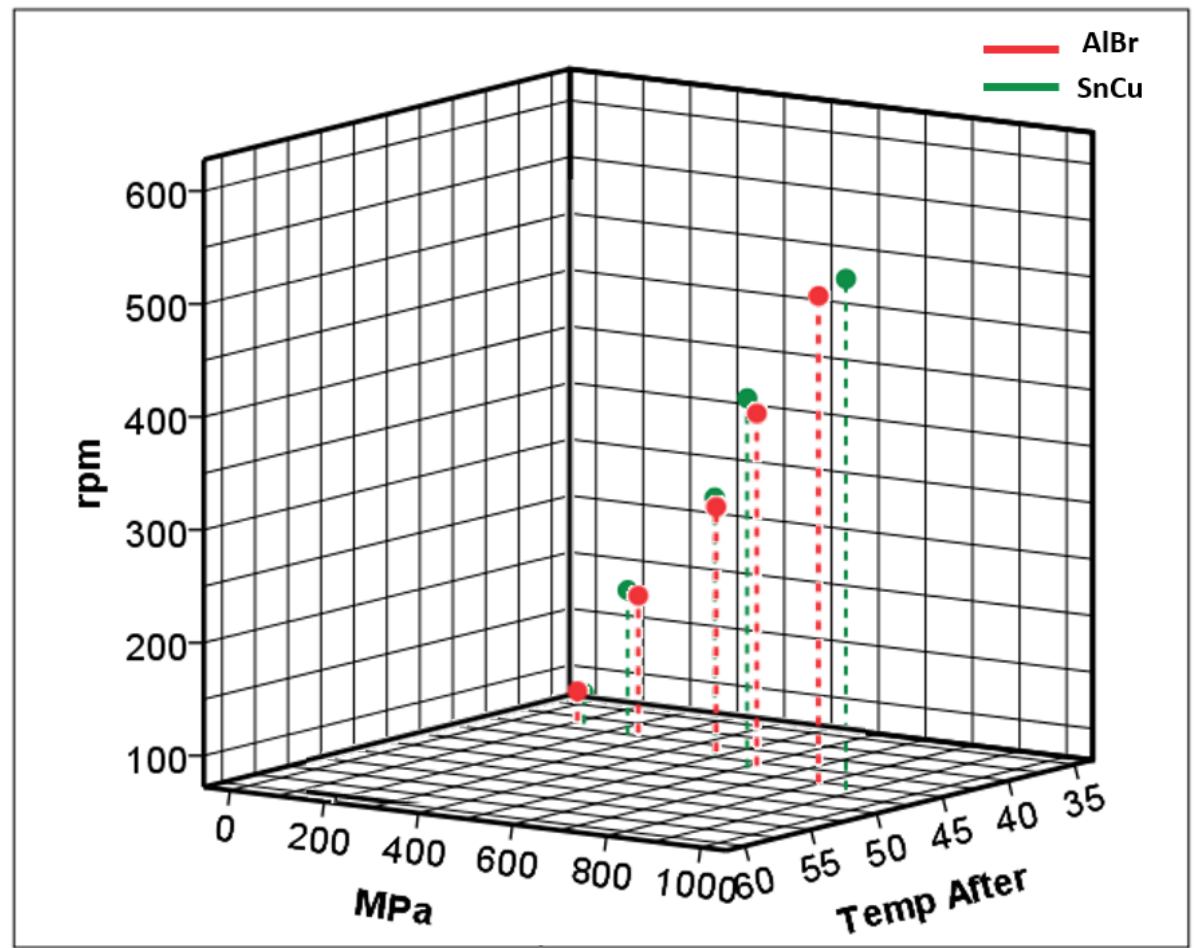

Gambar 11. Perbandingan Performa stern tube setelah repair

Dari Gambar 11, dapat diketahui setiap jenis material untuk bahan stern tube ini memiliki karakteristik yang hampir menyerupai. Ditinjau dari simulasi untuk menghitung beban kerja putaran poros dan tegangan yang terjadi memiliki nilai besaran yang identik. Pada Temperatur kerja antara material $\mathrm{AlBr}$ dan $\mathrm{CuSn}$ masing-masing memiliki range yang hampir sama antara $40-48^{\circ} \mathrm{C}$. Hasil proses reparasi menunjukan performa yang cukup baik, rata-rata temperature kerja yang dihasilkan ketika dilakukan pengujian sea trial menurun dari sebelumnya sebesar 7,5\%, sesuai yang tertera pada tabel 3 .

Tabel3.Stren TubePerformance Record

\begin{tabular}{ccc}
\hline \multirow{2}{*}{ Rpm } & \multicolumn{2}{c}{ Temperature $\left({ }^{\mathbf{0}} \mathrm{C}\right)$} \\
& Before repair & After repair \\
\hline 525 & 48 & 46 \\
400 & 48 & 44 \\
300 & 46 & 42 \\
200 & 44 & 40 \\
100 & 42 & 39 \\
\hline
\end{tabular}

\section{Kesimpulan}

Dari hasil penelitian yang telah tersaji sebelumnya maka dapat disimpulkan yaitu perbaikan bantalan poros propeller memerlukan perencanaan yang tepat dari segi desain dan material yang akan digunakan. Kemudian aplikasi penggunaan software finite elemen dapat menganalogikan kriteria karakter performa propeller baik sebelum ataupun sesudah reparasi. Sehingga proses perbaikan bantalan yang optimum dari beberapa referensi dapat menjadi gambaran referensi desain sebelum mengalami kerusakan. Adapun dalam hasil penelitian ini menunjukan metode perhitungan dengan numerik membantu dalam merekonstruksi pembebanan desain awal stern tube poros propeller yang telah mengalami 
Sulaiman dkk /Jurnal Rekayasa Mesin

p-ISSN: 1411-6863, e-ISSN: 2540-7678

Vol.16|No.3|369-378|Desember|2021

kerusakan. Dari hasil perhitungan dapat diketahui jika tegangan yang terjadi maksimum pada saat putaran propeller pada rpm mesin optimum. Maka nilai dari perbandingan performa dari jenis material perpaduan bronze yang berbeda menjadi salah satu pertimbangan pemilik kapal dalam hal ini kapal General Cargo 4192 GT Lintas Brantas dalam melakukan pengerjaan perbaikan stern tube yang efektif dan efisien.

\section{Ucapanterimakasih}

Terima Kasih kepada seluruh pihak yang telah mendukung dalam penulisan penelitian ini.

\section{Daftar Pustaka}

[1] Utomo B, Khristyson SF. Studi Perancangan Propulsi Kapal Peti Kemas 100 Teus. Gema Teknologi. 2019 Apr 30 ;20(2):46.

[2] Khristyson SF, Jamari, Bayuseno AP. Design of Fishing Vessel 5 GT for Traditional Fishing Community Activities. IOP Conference Series: Materials Science and Engineering . 2021;1096(1):12030.

[3] Lin C-G, Zou M-S, Sima C, Liu S-X, Jiang L-W. Friction-induced vibration and noise of marine stern tube bearings considering perturbations of the stochastic rough surface. Tribology International. 2019;131:661-71.

[4] Kuang F, Zhou X, Huang J, Wang H, Zheng P. Machine-vision-based assessment of frictional vibration in water lubricated rubber stern bearings. Wear . 2019;426-427:760-9.

[5] Khristyson SF, Jamari, Bayuseno AP. Stress analysis bottom plate block B-03 on patrol ship construction using finite element methods. IOP Conference Series: Materials Science and Engineering. 2021;1034(1):12004.

[6] Khristyson SF, Said SD, Wahid MA, Khoeron S. Keausan Poros Propeller yang Berlebihan Akibat Beban Radial Seal pada Lingkungan Air Laut. INOVTEK POLBENG. 2021;11(1):67-73.

[7] Guo H, Zou Z, Wang F, Liu Y. Numerical investigation on the asymmetric propeller behavior of a twin-screw ship during maneuvers by using RANS method. Ocean Engineering. 2020;200:107083.

[8] Feng D, Yu J, He R, Zhang Z, Wang X. Improved body force propulsion model for ship propeller simulation. Applied Ocean Research . 2020;104:102328.

[9] Wodtke M, Litwin W. Water-lubricated stern tube bearing - experimental and theoretical investigations of thermal effects. Tribology International. 2021;153.

[10] Litwin W, Dymarski C. Experimental research on water-lubricated marine stern tube bearings in conditions of improper lubrication and cooling causing rapid bush wear. Tribology International. 2016;95:449-55.

[11] Singh RP, Kumar S, Dubey S, Singh A. A review on working and applications of oxy-acetylene gas welding. Materials Today: Proceedings. 2021;38:34-9.

12] Thamilarasan J, Karunagaran N, Nanthakumar P. Optimization of oxy-acetylene flame hardening parameters to analysis the surface structure of low carbon steel. Materials Today: Proceedings. 2021.

[13] Lee J, Jeong B, An T-H. Investigation on effective support point of single stern tube bearing for marine propulsion shaft alignment. Marine Structure. 2019;64:1-17.

[14] Rossopoulos GN, Papadopoulos CI, Leontopoulos C. Tribological comparison of an optimum single and double slope design of the stern tube bearing, case study for a marine vessel. Tribology International . 2020;150:106343.

[15] Lee J. Application of strain gauge method for investigating influence of ship shaft movement by hydrodynamic propeller forces on shaft alignment. Measurement. 2018;121:261-75. 
Sulaiman dkk /Jurnal Rekayasa Mesin p-ISSN: 1411-6863, e-ISSN: 2540-7678

Vol.16|No.3|369-378|Desember|2021

[16] Zhang S, Long Z, Yang X. Reaction force of ship stern bearing in hull large deformation based on stochastic theory. International Journal of Naval Architecture and Ocean Engineering. 2020;12:723-32.

[17] He X, Xing P, Li G, Shang M, Zhang H. Investigation on evolvement of dynamic behaviors of ship stern shaftbearing system under the different rub-impact states based on attractor. Ocean Engineering. 2020;215:107733. 